DOI https://doi.org/10.18551/rjoas.2018-09.55

\title{
THE DEVELOPMENT OF FISHING COMMUNITIES IN CONDITIONS OF POST-IMPLEMENTATION OF MARITIME AND FISHERY MINISTER REGULATION NUMBER 02 YEAR 2015 IN TUBAN REGENCY
}

\author{
Amaludin Dhodik \\ Postgraduate School, University of Airlangga, Indonesia \\ E-mail: dhodik.amaludin@yahoo.com
}

\begin{abstract}
This study aims to determine and describe why the violation of the use of fishing gear that is not friendly to the environment still occurs and whether the empowerment of fishing community is already running according to expectation. From the research results obtained the overall picture of empowerment of the fishing through training held by the government's representatives.
\end{abstract}

\section{KEY WORDS}

Maritime, fishery, minister regulation, violation, development, fishing communities.

The minister of marine and fisheries Susi Pudjiatuti today concerned the realization of the Nawacita program that was initiated by President Jokowi is proven to be the achievement accomplished in managing and regulating fisheries and marine resources in Indonesia. Has already become popular if in the government related sphere of marine fisheries and very strict in enforcing the existing regulations in accordance with the mandate of law No.45 year 2009 regarding fisheries. In addition to tight against the foreign party the ministry of fisheries and marine resources are also tight on the society in the country. One of the proofs is the presence of the Minister of Marine and Fishery regulation No.2 year 2015 on the prohibition of the use of some fishing gears in the fisheries management area of Republic of Indonesia.

Many fishing communities that still use the capture tool is not eco-friendly indicate that regulation of the minister of marine and fishery no.2 year 2015 is not yet socialized evenly to all element of the fishing community in particular in Tuban regency. It is no wonder if there are still many fishing communities who do not know about these regulations so that the still remain use fishing gear that are not environmentally friendly in carrying out the activity of catching fish. The reason of the policy is to increase fish resources (SDI) and the preservation of the waters of the sea.

Some research this regulation does not impact the economy significantly but there are some obstacles such as the high cost of switching capture tool and community for this highly dependent on the use of fishing gear Cantrang conducted by Suhendra, Hendrik, \& Hamid (2016). Furthermore, a study conducted by Ermawati \& Zuliyati (2015), the result of research on the policy impact $1^{\text {st }}$. Social: unemployment is rising, the welfare of the fishing communities is declining and high of crime, $2^{\text {nd }}$ economic: the decline in the catch, income fell, with the economic conditions of fishermen: took the day off $(30 \%)$, switch to the other business $(40 \%)$, and work part time $(30 \%)$. However after the training program and grantmaking gear environmentally friendly (Gill Net) with the aim that the fishing community is powerless or has the ability for self in fact, there are still violations of fishing the recipient of a grant from the ministry of marine affairs and fisheries, namely by selling fishing gear and switch to tools that are not eco-friendly more (trawl).

The purpose of this study is to know the background of the fishing communities of program beneficiaries is still doing violations using fishing gear that are not environmentally friendly and whether community empowerment is already running according to expectation.

\section{LITERATURE REVIEW}

Community empowerment is an effort to the utilization and management of community resources more effectively and efficiently better than (a aspects of the input namely human 
resources, funds, equipment, data, plans and technology, (b) aspect of processes namely the implementation, monitoring and supervision, (c) aspect of output the achievement of objectives, effectiveness and efficiency (Rahardjo Adisasmita, 2006).

Rivai \& Sagala (2009:233-235) explain that there are criteria that are effectively used to evaluate the training activities that focused on the outcome.the managers and intructors need to pay attention to the following:

- The reaction of the participants to the process and content of the training activities;

- Knowledge or the process of learning acquired through the training experience;

- Behavior change due to training activities;

- The result or improvement both for individuals and organizations.

\section{METHODS OF RESEARCH}

The approach used in this research is descriptive qualitative approach. This research was conducted at the three places, i.e. subdistricts of Bancar, Tambakboyo and Jenu in Tuban Regency, East Java, Indonesia. Informants in this study were seven persons selected to randomly to the community who has experience with the focus of this research, expected to provide correct information and clear among other things from the fishermen of grant recipients capture tool and training, the department of fisheries and animal husbandry district of Tuban and the instructors from the institute for development training of fisheries (BP3) Banyuwangi.

\section{RESULTS AND DISCUSSION}

Based on the results of interviews and the collection of data obtained from information about the empowerment of fishing communities through the provision of grant of fishing gear environmetally friendly as well as training to fishermen in order to support the implementation of the ministerial regulation no. 2 year 2015 is as follows:

In an effort utilization and resource management fishing communities in order to more effectively and efficiently i.e. the input consist of several factors, among others, human resources, fund, equipment, data, plans and technology, but for the factor of technology is not used due to replacement of fishing gear in this operation are still traditionally there has been no addition technology to catch fish.

Policy actors or stakeholder are from the government regards this instructor training, the department of fisheries and animal husbandry of Tuban regency and the fishermen affected by the impact of the policy, namely the fishermen of grant recipient capture tool and training program.

Since the issuance of regulation of minister of marine and fishery no.2 of the year 2015 as the governments' efforts in the process of empowerment of fishing communities that have fishing gear that is banned then the government in this case ministry of marine affairs and fisheries grants fishing gear to the fishermen with small vessel size $<10$ GT (Gross Tonage) as much 293 units at 22 of the group.

As the narrative of the informant Priyo Anggodo from the department of fisheries and animal husbandry Tuban Regency is as follows: "Delivery of fishing gear grant from the ministry of marine affairs and fisheries, not all members of the group get the fishing gear due to the customized with the fishermen "A3" or Trawl and "B0" of the ship is not engine wear, "B1" size vessels less than 10 Gross Tonnage, fishing gear donated is a Gill Net basic and Gill Net mid with a total of 22 groups (Priyo Anggodo, interview, May $6^{\text {th }}, 2018$ )".

In the grant program fishing gear and training completely using the budget of the ministry of marine affairs and fisheries year 2016 and 2017 as said by the speaker the following: "The budget comes from the central government in the form of fishing gear ecofriendly and the training program in 2016 and 2017 (Priyo Anggodo, interview, May $6^{\text {th }}$, 2018)". 
Similarly, informants Nyoman Budiarta of the training center development of fisheries as: "The cost of training, materials, practice, be borne by the fund of state APBN in 2017 as many as 90 people (Nyoman Budiarta, interview, May $6^{\text {th }}, 2018$ )".

In the year 2016 Ministry of Maritime affairs and Fisheries distribute fishing equipment in the form of a catcher of fish fat in accordance with the proposals submitted by the fishermen of candidates to the Ministry of Marine affairs and Fisheries of the grinding tool is a new Bangkinang who use fishing gear which is not environmentally friendly i.e. trawling then it needs to be given knowledge in the form of training so that at the time of the transition from fishing gear the old to the new can already operate well, in this case the researchers want to assess how much knowledge has been gained through the training.

This was stated informant Nyoman Budiarta of the Training center development of fisheries Banyuwangi as follows: "In the training of the 293 people who receive fishing gear gill net only 90 people who follow the training program for 4 days in 3 districts covering the theory and practice of how to use the capture tool of a new and deliver the knowledge content of the policy of the minister of marine and fisheries, but it is expected of members who participate in the training can channel their knowledge to the members who did not attend the training so that the new tool can be used properly (Nyoman Budiarta, interview, May $\left.7^{\text {th }}, 2018\right)$ ".

There are two factors in the process of community empowerment for effective and efficient implementation and monitoring in the process of implementation of the Regulation of the Minister of Marine and Fisheries in the described there is some fishing gear that are prohibited in article 4 of the regulation of the minister of marine and fishery no. 2 of the year 2015.

The implementation of this research was conducted by interviewing 5 fishermen who get a grant capture tool and follow the training for 4 days with the material that describes the contents and purpose of the policy of the minister of marine and fisheries. This regulation has been implemented to fishing after following the training, such as explanation of the informants as follows: "To know well over the regulation of the material presented during the training with the goal of keeping the ecosystem of the waters of the sea will be preserved, (Sudik, fishermen, interview May $5^{\text {th }}, 2018$ ).

It is also disclosed by the informant fishermen other as follows: "More detailed information about the policy at the time of training held by the training center of development of fisheries Banyuwangi (Zaenal Abidin, fishermen, interview, May $7^{\text {th }}, 2018$ ).

In the needs assessment can be aware of the problems and future challenges that must be faced by training and development, disclosed by the informant Sudik as a fisherman as follows: "There are some people from the fishing grantees fishing gear but did not get a training program sell the tool to additional buy a boat because the boat used did not allow to operate in a far distance because it is feared will be damaged by the waves and if the new tools are in use in short distance then the fishermen do not get fish, it needed a push or an opportunity for members who have not attended training to be included in the next training" sudik, fisherman, interview, May $\left.5^{\text {th }}, 2018\right)$ ".

It is also expressed by the informants other fishermen as follows: "Production decline of catching fish unless the arrest is done around coral reefs but if you operate in a place around coral reefs new tool or gill net snagged and damaged, it is not given the knowledge at the time of training (Saniman, fisherman, interview, May $7^{\text {th }}, 2018$ )".

After the passage of the grant program fishing gear and training necessary process monitoring with the aim to determine the extent to which the program is running whether in accordance with the target or not, so that the program can contribute and change the welfare of the fishermen, especially fishermen who were adversely affected by the policy. as stated by the informants as follows: "After the training which was held June 2017 no one ever came to ask development about grant and what obstacles faced during this time (Saefudin, fisherman, interview, May $\left.5^{\text {th }}, 2018\right)$ ".

It is also stated by the informant from the fishermen as follows: "The department of fisheries and animal husbandry Tuban regency and the training center for development of 
fisheries Banyuwangi never asked the constraints faced by the fishermen beneficiaries of the program (Kosip, fisherman, interview May $7^{\text {th }} 2018$ )".

Phrase from the department of fisheries and animal husbandry Tuban regency, Priyo Anggodo as follows: "Asked if the grant is already operated with better yet, how the catch from the fishing gear gill net and been informed that the tool capture the grant May not be sold (Priyo Anggodo, interview May 10 ${ }^{\text {th }}, 2018$ )".

The same thing also expressed by Nyoman Budiarta instructor training center development of fisheries: "Monitoring in writing has not been done the plan 2018 will be training by the extension workers of the ministry of marine affairs and fisheries, who served in the regency of Tuban (Nyoman Budiarta, interview May $7^{\text {th }} 2018$ )".

Changes in the knowledge and skills obtained by the fishermen recipient of grants and training programs still can't push fully the fishermen to change fishing habits on the day, such as the expression conveyed by the informant below: "The members of the fishermen never using fishing gear gill net in the daytime and the result is zero, to switch the habit of catching fish at night need encouragement from the relevant agencies to do the practice the night so the fishermen do not feel fear and worry so that some of the tools are still stored not come with sale (sudik, fisherman, interview May $5^{\text {th }}, 2018$ ).

As for the constraints faced by the training providers in the practical session in the sea is strongly influenced by the weather as conveyed by the informant Nyoman Budiarta as follows: "In the implementation of fishing practices we are already planning for the night due to weather that does not support and a very limited time then held on during the day and also the tool gill net is a passive (Nyoman Budiarta, interview May $7^{\text {th }} 2018$ )".

\section{CONCLUSION}

According to the analysis, it can be concluded as follows:

- The fishermen recipient of the grant and training program already has knowledge about this regulation;

- The fishermen beneficiaries of the program cannot change the habit in catching fish by using fishing gear Gill Net is effective carried out at night so that the tool submitted could not be maximized in its use;

- The absence of periodic monitoring and written after the program is implemented;

- Uneven training, which was held only a part or a representative of a group included because of limited budget from the government.

\section{ACKNOWLEDGEMENTS}

The author would like to thank Dr. Sutinah Dra as the supervisor for this research.

\section{REFFERENCES}

1. Adisasmita, Rahardjo. 2006. Pembangunan Pedesaan dan Perkotaan. Yogyakarta: Graha IImu

2. Ermawati, N., \& Zuliyati. (2015). Dampak Sosial Dan Ekonomi Atas Peraturan Menteri Kelautan Dan Perikanan Nomo 2/PERMEN-KP/2015 (Studi Kasus Kecamatan Juwana Kabupaten Pati). Prosiding Seminar Nasional Multi Disiplin IImu \& Call For Papers Unisbank (SENDI_U).

3. Rivai, V., \& Sagala, E. J. (2009). Manajemen Sumber Daya Manusia Untuk Perusahaan; Dari Teori ke Praktik. Jakarta: Rajawali Press.

4. Suhendra, R., Hendrik, \& Hamid, H. (2016). The Impact Of Permen-KP No. 2 Tahun 2015 Policy About Prohabition On Operating Cantrang (Catching Tool) To The Economic Condition Of Fishermen In Raja Bejamu Village, Sinaboi Distric, Rohil, Riau Province. Jurnal IImiah. 